\title{
Social Marketisation and Policy Influence of Third Sector Organisations: Evidence from the UK
}

\author{
Jun Han 1
}

Published online: 8 March 2017

(C) The Author(s) 2017. This article is published with open access at Springerlink.com

\begin{abstract}
The marketisation of social sector organisations or social marketisation emerged and spread around the world in the past three decades. In contrast with existing literature which claims that social marketisation makes social sector organisations reduce their efforts on advocacy and thus harms a civil society, this research argues that social marketisation is positively contributed to the influence of third sector organisations on government policies, and thus it strengthens civil society, rather than erodes it. Based on the National Survey of Charities and Social Enterprises in the UK, the results of regression analyses indicate clearly that, when other factors are equal, the two indicators of social marketisation, social entrepreneurship and achieving government contracts for purchasing services, are both statistically significant in estimating the level of policy influence of third sector organisations. The contribution of this research is that it finds a positive, instead of a negative, relationship between social marketisation and the perceived policy influence of third sector organisations.
\end{abstract}

Résumé La marchéisation d'organismes du secteur social, ou marchéisation sociale, a vu le jour et s'est répandue dans le monde au cours des trois dernières décennies. Contrairement à la documentation existante, qui affirme que la marchéisation sociale incite les organismes du secteur social à réduire leurs initiatives de défense et porte ainsi préjudice à la société civile, la présente recherche argumente que la marchéisation sociale contribue positivement à l'influence qu'ont les organismes du tiers secteur sur les politiques gouvernementales, renforçant ainsi la société civile au lieu de l'éroder. Fondés sur l'enquête nationale des organismes de bienfaisance et entreprises sociales du Royaume-Uni, les résultats des analyses

Jun Han

Jun.han@sociology.ox.ac.uk

1 Department of Sociology, University of Oxford, Manor Road Building, Manor Road, Oxford OX1 3UQ, UK 
de régression démontrent clairement que, si les autres facteurs sont égaux, les deux indicateurs de la marchéisation sociale, soit l'esprit d'entreprise sociale et la signature de contrats gouvernementaux pour l'achat de services, jouent un important rôle statistique dans le calcul du niveau d'influence politique estimé des organismes bénévoles. La contribution de la présente recherche est la suivante : elle établit un lien positif, non négatif, entre la marchéisation sociale et l'influence politique perçue des organisations du tiers secteur.

Zusammenfassung Die Vermarktlichung von Organisationen im sozialen Sektor bzw. die soziale Vermarktlichung entstand und verbreitete sich weltweit in den vergangenen drei Jahrzehnten. Im Gegensatz zur vorhandenen Literatur, derzufolge die soziale Vermarktlichung dazu führt, dass die Organisationen im sozialen Sektor ihre Bemühungen zur Interessenvertretung reduzieren, und sie somit einer Bürgergesellschaft schadet, behauptet die vorliegende Studie, dass sich die soziale Vermarktlichung positiv auf den Einfluss seitens Dritter-Sektor-Organisationen auf die Regierungspolitik auswirkt und daher die Bürgergesellschaft stärkt und nicht untergräbt. Beruhend auf der nationalen Befragung von Wohltätigkeitsorganisationen und Sozialunternehmen in Großbritannien (National Survey of Charities and Social Enterprises) weisen die Ergebnisse der Regressionsanalysen deutlich darauf hin, dass - sofern alle anderen Faktoren gleich sind - die beiden Indikatoren für soziale Vermarktlichung, soziales Unternehmertum und die Sicherstellung von Regierungsaufträgen über den Kauf von Dienstleistungen statistisch signifikant sind, um den Grad der Einflussnahme seitens Dritter-Sektor-Organistationen auf die Politik zu messen. Das Ergebnis der Studie ist, dass die Beziehung zwischen der sozialen Vermarktlichung und der wahrgenommenen politischen Einflussnahme seitens Dritter-Sektor-Organisationen eher positiv als negativ ist.

Resumen La marquetización de las organizaciones del sector social o la marquetización social surgió y se extendió por todo el mundo en las últimas tres décadas. En contraste con el material publicado existente que reivindica que la marquetización social hace que las organizaciones del sector social reduzcan sus esfuerzos en defensa y perjudica de este modo a una sociedad civil, la presente investigación argumenta que la marquetización social ha contribuido positivamente a la influencia de las organizaciones del sector terciario en las políticas gubernamentales, y de este modo fortalece a la sociedad civil, en lugar de erosionarla. Basándose en la Encuesta Nacional de Empresas Sociales y Benéficas en el Reino Unido, los resultados de los análisis de regresión indican con claridad que, cuando otros factores son iguales, los dos indicadores de la marquetización social, el emprendimiento social y la obtención de contratos gubernamentales para la compra de servicios, son ambos estadísticamente significativos a la hora de estimar el nivel de la influencia política de las organizaciones del sector terciario. La contribución de esta investigación es que encuentra una relación positiva, en lugar de negativa, entre la marquetización social y la influencia política percibida de las organizaciones del sector terciario.

Keywords Social marketisation · Policy influence $\cdot$ Third sector organisations · UK 


\section{Introduction}

The past three decades have witnessed the marketisation of social sector organisations around the world. The marketisation of the social sector means that non-profit organisations becoming "more market driven, client driven, selfsufficient, commercial or business like", (Dart 2004, p. 414). This research defines the marketisation of social sector organisations as "social marketisation". Basically, social marketisation refers to the tendency of using entrepreneurial and marketised strategies by third sector organisations in their survival, growth, and interactions with the government. It includes two indicators: social entrepreneurship and achieving government contracts for purchasing services.

Traditionally, social sector organisations primarily rely on donations or giving. A new phenomenon is emerging and growing, whereby an increasing number of third sector organisations are developing their own funding streams by selling products or services to customers, corporations, foundations, or the government. This phenomenon is important, because it indicates that social organisations are devising their own solutions, in the form of professional services, to address social problems or meet social demands. As a consequence, the proportion of their service income out of the overall revenue is growing. When the commercial income increases significantly (usually more than $35 \%$ or $50 \%$ ), a social sector organisation has transformed into a social enterprise (Han 2013). What distinguishes social enterprises from for-profit enterprises is the way in which they use their profits. Social enterprises devote a significant proportion (usually $50 \%$ or more) of their profits to pursue social or environmental goals, rather than $100 \%$ shared by their shareholders (Han 2013).

Meanwhile, government procurements of services from third sector organisations have emerged and spread. Government procurement of services can create a marketbased mechanism and a relatively equal playing field for social organisations to compete with each other in providing services and addressing social issues. Theoretically, the achievement of government contracts thus more relies on social organisations' performance in solving social problems and meeting social demands, and less on their backgrounds or government ties.

Regarding the impact of the two new phenomena, existing literature claims that the marketisation of the social sector threatens or harms creating or maintaining a strong civil society (Eikenberry 2009; Eikenberry and Kluver 2004; Nickel and Eikenberry 2009). One of the reasons is that marketisation makes social sector organisations reduce their time and efforts on advocacy for public goods, but increase emphases on management concerns and short-term profitability (Eikenberry 2009, p. 137). This research, however, suggests that the tendency of social marketisation may strengthen the development of civil society, because it can enhance the involvement of third sector organisations on government policy making and improves the level of their influence on government policies.

There is a good reason to expect that social marketisation is positively related to a higher level of policy influence of third sector organisations. In a modern society, as social problems and social demands emerge and develop, social organisations can 
design and undertake professional services, as their unique solutions, to address complex social issues. As their service income grows and when they devote their half or more profits to addressing social issues, social organisations can address social problems in a more sustained and effective way. When they address social issues sustainably and effectively, they are more likely to make a difference to these issues. When social organisations garner the evidence that their solutions are effective in addressing social issues, or in other words they have created positive social change, they can use the evidence of positive social change to persuade the government, either directly or indirectly, to change its attitudes, behaviours, or policies. Therefore, the seemingly service-oriented marketisation process in the social organisation sector may, in the end, enhance the influence of third sector organisations on the related government policies on the social issues.

This research focuses on third sector organisations in the UK. The UK is the earliest and still a leading country in the development of social marketisation. Since the 1980s, the UK government has created many policies to foster efficient markets for third sector organisations to deliver public goods and services (Newman 2007). In 2001, the Department of Trade and Industry (DTI) set up a Social Enterprise Unit to provide support for social enterprises. This unit was incorporated into the Office for the Third Sector (OTS) in 2006, which was re-titled as the Office for Civil Society in the Cabinet Office in 2010 (Hall, Alcock and Millar 2012). In 2002, the national umbrella body, Social Enterprise UK, has been established. In 2005, the Community Interest Company (CIC) was set up as a new legal category for the registration of social enterprises in the UK. In 2009, the Department of Health established the Social Enterprise Investment Fund (SEIF) to assist social enterprises in delivering health and social care services. In 2010, all major parties in the UK announced support for the development of social enterprises. After the election 2010, Prime Minister David Cameron launched the "Big Society" scheme, one of its core strategies is to enhance the role of charities, social enterprises, and voluntary organisations in addressing social issues and meeting social demands. In 2011, the world's first Social Impact Bond appeared in Britain. In 2012, Big Society Capital was launched in London. In 2013, Social Value Act was promulgated, Social Stock Exchange was founded, and G8 Social Investment Task Force was set up. The rapid development of social enterprises and financial support from the government made the UK become one of the best places to test the social marketisation thesis.

The following section of this article is organised as follows. Firstly, it reviews the literature on the factors affecting the policy influence of third sector organisations on government policies. Next, it presents the data used in this research and the measurements of dependent and independent variables. Finally, this research reports the results, draws the conclusion, and discusses the contribution and weakness of this research. 


\section{Literature Review}

Based on the proposed hypothesis and existing literature, this research identifies three groups of factors to estimate the level of influence of third sector organisations on government policies. The three groups of factors are (1) social marketisation, (2) resources, and (3) institutional factors.

\section{(1) Social Marketisation}

As aforementioned, social marketisation refers to entrepreneurial and marketised strategies that social organisations use to survive, thrive, and interact with the state. It includes social entrepreneurship and achieving government contracts for purchasing services.

Social entrepreneurship means drawing upon business techniques to address social problems and create sustainable social changes (Dees 1998; Nicholls 2006). Social enterprises play a significant role in the social sector, by creating and sustaining social values, not only economic values (Dees 1998). What distinguishes social enterprises from other social sector organisations is the generation of commercial income. Commercial income may include "program service fees, the sale of products not directly associated with the charitable activity, contracts to deliver services on behalf of a third party, profits from for-profit subsidiaries, and fees for endorsing products" (McKay et al. 2015, p. 340). Similarly, according to Salamon (1993) and Young et al. (2012), the substantial growth of service fees and sales as an income source of nonprofit organisations is a significant dimension of the marketisation of the non-profit sector. McKay et al. (2015) define the marketisation of non-governmental organisations (NGOs) as substituting grants and donations with commercial revenue. Weisbrod (2000) also notes that non-profit organisations are mimicking private firms, and there is a shift in the financial dependence of social organisations from charitable donations to commercial sales activities.

Not all social sector organisations that generate commercial revenue are social enterprises. How to use the profits is the key. According to one of the qualification criteria set by an SE certification agency in the UK (the Social Enterprise Mark), "over $50 \%$ of the profits generated from commercial activities are dedicated to social purposes" distinguishes a social enterprise from a business (100\% profit distribution). ${ }^{1}$ Therefore, only when social sector organisation uses $50 \%$ or more of the surpluses or profits to further the social or environmental goals, it can be regarded as a social enterprise (Han 2013).

The second dimension of social marketisation is achieving government contracts for purchasing services. Contract-based relations with the government are different from co-optation or corporatist relations. In the corporatist arrangement, social organisations receive government grants and subsidies, depending on their "singular, compulsory, non-competitive" status and leadership co-optation (Schmitter 1974, pp. 93-94). In government procurement of services, SOs compete with each other, and there are no organisations enjoying monopolistic status in interest

\footnotetext{
${ }^{1}$ The full details of the criteria set by the Social Enterprise Mark see: http://www.socialenterprisemark. org.uk/wp-content/uploads/2014/05/SEM_Qualification_criteria_July-12.pdf.
} 
representation and resource distribution. Achieving government contracts thus relies more on the capacity and performance of the organisation in tackling social problems and meeting social demands, and less on their background or government ties.

Signing contracts with the government in solving social problems and meeting social demands can help establishing an institutional channel of information exchange and mutual learning between social sector organisations and the government. Social organisations can use this channel to inform the government how they address social issues and how well they address them. When the government perceived that the approaches or solutions of social organisations are effective in alleviating social problems, it becomes more willing to adopt similar approaches, or to help scale up the effective solutions from social sector organisations to address the social issues. The consequence is that the level of involvement and influence of social sector organisations is improved in the process. Based on the notion of social marketisation, this paper proposes Hypothesis 1: Social marketisation is positively related to the level of influence of third sector organisations on government policies.

\section{(2) Resources}

According to resource mobilisation theory (Jenkins 1983; McAdam et al. 1988; McCarthy and Zald 1977), social actors require and mobilise personnel, financial, and other resources to carry out activities and pursue their goals. Likewise, resource dependence theory (Aldrich and Pfeffer 1976; Aldrich 1979; McCarthy and Zald 1977; Pfeffer and Salanick 1978) believes that organisations rely on resourcesfunding, people, information, and even recognition-from the external world to survive and thrive. Therefore, resources from the external environment play a significant role in shaping organisational decisions and behaviours, including their policy influence.

It is reasonable to expect that social organisations with more resources have a higher level of influence on government policies. Extant literature has shown that the availability of financial and human resources enhances collective actions (Andrews and Edwards 2004). The scope and intensity of advocacy activities are greater in organisations with larger budgets and larger staff size (Bass et al. 2007; Child and Grønbjerg 2007; Donaldson 2007; Mosley 2010; Nicholson-Crotty 2007). Conversely, the lack of resources is a primary barrier to conduct advocacy activities and to pursue policy changes (Almog-Bar and Schmid 2014; Bass et al. 2007).

Based on the existing literature, this research identifies two main resources social sector organisations have in affecting government policies, financial resources and human resources. Financial resources are the scale of income of the organisation. Human resources are the size of full-time staffs and part-time volunteers of the organisation. The research of Schmid et al. (2008), for example, has indicated that the larger number of volunteers in the organisation, the greater political influence the organisation has. Financial and human resources are thus expected to have positive associations with the level of social organisations' influence on government policies. Based on resource dependence theory and resource mobilisation theory, this paper expects Hypothesis 2: Financial resources and human resources are 


\section{positively related to the level of influence of third sector organisations on government policies.}

\section{(3) Institutional factors}

In addition to resources, institutional factors are essential for social organisations to influence government policies. Neo-institutional theory highlights the role of a broader institutional environment. Neo-institutional theory posits that organisational structures and behaviours are largely shaped by the institutional or normative environment, instead of just reflecting resource dependencies or being determined by organisational strategies (DiMaggio and Powell 1983; Meyer and Rowan 1977; Meyer and Scott 1983; Powell and DiMaggio 1991; Scott 2004; Scott and Christensen 1995; Scott et al. 1994; Zucker 1987). In order to survive and grow, organisations have to conform to the rules, norms, values, standards, and expectations prevailing in the institutional environment.

When organisations are subject to largely the same institutional environment, they become increasingly similar to one another over time, or become "isomorphic". DiMaggio and Powell (1983) distinguish three mechanisms of isomorphic pressures (coercive, mimetic, and normative isomorphism). Similarly, Scott summarises "three pillars" of institutionalisation-regulative, normative, and cultural-cognitive. The regulative pillar consists of rules, laws, and sanctions, the normative pillar involves certification and accreditation, and the cultural-cognitive pillar includes common beliefs and shared logics of action (Scott 2001, p. 52).

Social organisations working in the same issue area confront almost the same institutional environment. Social organisations working in different issue areas do not equally engage in activities to influence government policy, and their level of policy influence thus may vary. For example, Child and Grønbjerg (2007) indicate that non-profit organisations working in the fields of environment, health, and mutual benefits are more likely to engage in advocacy than human service organisations. Suárez and Hwang (2008) reveal that environmental organisations, civil rights groups, parent-teacher organisations (education), and hospitals (health) are more likely to lobby the government than organisations in other fields. Baumgartner and Leech (2001) also find that interest groups tend to focus on a small number of issues. Therefore, social organisations working in different issue areas are expected to have different levels of policy influence.

The geographical region of operation is the second salient institutional factors. Some third sector organisations carry out their activities at the international level, some undertake activities nationwide, while some work only in the regional or local areas. As noted by Hsu et al. (2016) that resource strategies of NGOs have regional variances, one may expect that the regional differences of policy influence of social organisations also exist. Specifically, social organisations working at the international or national level are expected to be more active than organisations working in the regional, local, or neighbourhood areas. Therefore, based on the neoinstitutional theory and existing studies, one may suggest Hypothesis 3: Issue areas and geographical regions affect the level of influence of third sector organisations on government policies. 
In sum, based on the social marketisation hypothesis and existing literature as discussed above, this paper builds an analytical framework by combing three groups of factors to examine the level of influence of third sector organisations on government policies, as outlined in Fig. 1.

\section{Data, Variables and Measurements}

To test the three hypotheses, this research uses a large-scale survey data from the UK, namely the National Survey of Charities and Social Enterprises (NSCSE). NSCSE, formerly known as the National Survey of Third Sector Organisations (NSTSO), was initiated by the Office for Civil Society of Cabinet Office UK and implemented by Ipsos MORI, Social Research Institute. In 2010, the investigators submitted survey invitations to 112,796 third sector organisations (charities, voluntary organisations and social enterprises) across all 151 single and two-tier authorities in the UK. A total of 44,109 organisations completed the postal or online questionnaire. The overall valid response rate is $41 \%$. The questionnaire was to be completed by the leader of the organisation, a member of the senior management, or a member of the trustee board or management committee. The database NSCSE is now completely open accessed to scholars based in the UK. ${ }^{2}$ More details of NSCSE, including sampling method, data processing, and questionnaire content, can be found in the online technical report. ${ }^{3}$ The following section describes how the variables used in this research are measured in the survey questions.

\section{(1) Three variables of policy influence}

In NSCSE, policy influence of third sector organisations is measured by three variables: (1) overall policy influence, (2) policy involvement, and (3) policy consulting. In terms of overall policy influence, one question in the survey asked: "Overall, how satisfied or dissatisfied are you with your ability to influence government decisions that are relevant to your organisation? The options are (1) very satisfied, (2) fairly satisfied, (3) neither satisfied nor dissatisfied, (4) fairly dissatisfied, (5) very dissatisfied, (6) don't know, and (7) not applicable" (Q22 in the survey). The answers to options 1 to 5 are coded from five to one, respectively. A higher score means a higher level of policy influence.

In terms of policy involvement, one question in the survey enquired: "To what extent do you agree or disagree with the following statements: local statutory bodies in your local area involve your organisation appropriately in developing and carrying out policy on issues which affect you? (1) Strongly agree, (2) tend to agree, (3) neither agree nor disagree, (4) tend to disagree, (5) strongly disagree, (6) don't know, and (7) not applicable" (Q21 in the survey). The answers to options 1 to 5 are

\footnotetext{
${ }^{2}$ See the website: https://discover.ukdataservice.ac.uk/catalogue/?sn=7347\&type=Data\%20catalogue. Researchers based on the UK can login the website (https://www.ukdataservice.ac.uk) and download the database by using their institutional email account.

3 The technical report can be downloaded from the link: http://doc.ukdataservice.ac.uk/doc/7347/mrdoc/ pdf/7347_nscse_technical_report_2010.pdf.
} 


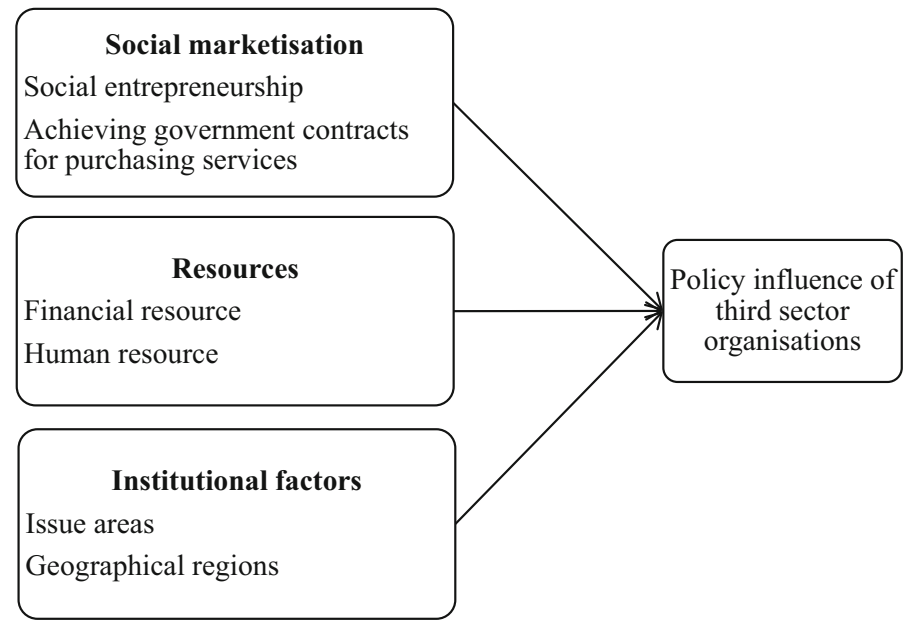

Fig. 1 Analytical framework

coded from five to one, respectively. A higher score means a higher level of policy influence.

In terms of policy consulting, the survey asks: "To what extent do you agree or disagree with the following statements: local statutory bodies consult your organisation on issues which affect you or are of interest to you? (1) Strongly agree, (2) tend to agree, (3) neither agree nor disagree, (4) tend to disagree, (5) strongly disagree, (6) don't know, and (7) not applicable" (Q21 in the survey). The answers to options 1 to 5 are coded from five to one, respectively. A higher score means a higher level of policy influence.

\section{(2) Social marketisation}

In NSCSE, social entrepreneurship is measured by key variables: whether the organisation use the profit or surplus generated in their commercial activities to pursue social goals. The question in the survey asks: "If your organisation does generate a surplus or profit from its contracts or trading, do you use it to further your social or environmental goal? This could include reinvesting it in your or another charity, social enterprise and/or voluntary organisation or in the community. Options are (1) yes-we use up to $50 \%$ of the surplus/profit, (2) yes-we use $50 \%$ or more of the surplus/profit, (3) not applicable-we do not make a surplus/profit, (4) no, and (5) don't know" (Q37 in the survey). Answers to option two are coded as one, and otherwise as zero.

Achieving government contracts for purchasing services is based on one question in the survey: "How successful, or not, have you been in applying for funding or bidding for contracts from local statutory bodies over the last 5 years? ${ }^{4}$ Options are (1) very successful, (2) fairly successful, (3) not very successful, (4) not

\footnotetext{
4 As defined in the survey, local statutory bodies are "local public sector organisation set up by government to meet specific objectives and undertake agreed activities, e.g. local councils, primary care trusts (PCTs) and local police authorities" (see page 10).
} 
at all successful, (5) have never applied/bid, and (6) don't know" (Q15 in the survey). Answers to options 1 and 2 are coded as one, answers to options 3-5 are coded as zero, and answers to option 6 are coded as missing values.

\section{(3) Resources}

In NSCSE, financial and human resources are measured by three variables: income size, staff size, and volunteer size. In terms of income size, one question in the survey asked: "Please indicate below your organisation's approximate annual total turnover or income from all sources" (Q33 in the survey). The answers to this question are coded from 1 to 24 , based on the size of the income. ${ }^{5}$ A higher score means a larger size of income.

In terms of staff size, one question requested: "Please tell us the approximate number of full-time equivalent employees currently in your organisation" (Q30 in the survey). The answers of no employees are coded as 1, the answers of one employee are coded as 2, two employees are coded as 3, 3-5 employees are coded as 4, 6-10 employees are coded as 5, 11-30 employees are coded as 6, 31-100 employees are coded as 7, and 101 plus employees are coded as 8 . No answers are coded as missing values. A higher score means a larger size of full-time employees.

In terms of volunteer size, the question enquired: "Please tell us the approximate number of volunteers, including committee/board members, that your organisation currently has" (Q31 in the survey). No volunteers are coded as 1, 1-10 volunteers are coded as 2, 11-20 volunteers are coded as 3, 21-30 volunteers are coded as 4, 31-50 volunteers are coded as 5, 51-100 volunteers are coded as 6, 101-500 volunteers are coded as 7, 501 plus are coded as 8 . No answers are coded as missing values. A higher score means a larger group of volunteers in the organisation.

\section{(4) Institutional factors}

In NSCSE, institutional factors include issue areas and geographic areas. In terms of issue areas, one question asked: "Which are the main areas in which your organisation works? (Q4 in the survey) Options are: (1) community development and mutual aid, (2) cohesion/civic participation, (3) culture (including arts and music), (4) leisure (including sports and recreation), (5) economic well-being (including economic development, employment and relief of poverty), (6) accommodation/housing, (7) education and lifelong learning, (8) training, (9) environment/sustainability, (10) equalities/civil rights (e.g. gender, race, disabilities), (11) heritage, (12) health and well-being, (13) international development, (14) religious/faith-based activity, (15) criminal justice, (16) animal welfare, (17)

\footnotetext{
5 The coding methods are as follows. No income is coded as 1, 1-500 GBP are coded as 2, 501-1000 are coded as 3, 1001-2000 are coded as 4, 2001-3000 are coded as 5, 3001-5000 are coded as 6, 5001-7000 are coded as 7, 7001-9000 are coded as 8, 9001-10,000 are coded as 9, 10,001-12,000 are coded as 10, 12,501-17,000 are coded as 11, 17,501-20,000 are coded as 12, 20,001-30,000 are coded as 13, $30,001-40,000$ are coded as 14, 40,001-60,000 are coded as 15, 60,001-80,000 are coded as 16, $80,001-100,000$ are coded as 17, 100,001-150,000 are coded as 18, 150,001-200,000 are coded as 19, 200,00-300,000 are coded as 20,300,001-500,000 are coded as 21,500,001-1,000,000 are coded as 22, $1,000,00-5,000,000$ are coded as 23, 5,000,001 plus are coded as 24 .
} 
capacity-building and other support for charities, (18) other charitable, social or community purposes." These options are coded from 1 to 18 , respectively.

For geographic areas, the question in the survey enquired: "Which one is the main geographic area in which your organisation carries out its activities? (1) Internationally, (2) nationally, (3) regionally, (4) your local authority area, (5) your neighbourhood, or (6) cannot say" (Q8 in the survey). The answers to options 1-5 are coded from five to one, respectively, and answers to option 6 are coded as missing values.

\section{Results}

Table 1 reports the coding methods and descriptive statistics of all variables used in this research. The data of NSCSE reveals that, on average, the satisfaction of third sector organisations on their policy influence is 2.8 (1-5 scale). $2.1 \%$ of third sector organisations in the UK were very satisfied with their ability to influence policy. $14.3 \%$ of third sector organisations are fairly satisfied with their ability to influence policy. $22.5 \%$ of third sector organisations neither satisfied nor dissatisfied.

In terms of policy involvement and policy consulting, the average score of policy involvement is 2.7 (1-5 scale), and the average level of policy consulting is 2.9 (1-5 scale). Specifically, $3.9 \%$ of third sector organisations "strongly agree" that they were involved in developing and carrying out policy, and 5.2\% of third sector organisations "strongly agree" that they were consulted by the government on issues which affect them or are of interest to them. $13.9 \%$ of third sector organisations "tend to agree" that they were involved in developing and carrying out policy, and $18.5 \%$ of third sector organisations "tend to agree" that they were consulted by the government on issues which affect them or are of interest to them.

Regarding the two key indicators of social marketisation, the data shows that $44.7 \%$ of third sector organisations in the UK become social enterprises, as they devote half or more of their profits or surpluses generated in their commercial activities to pursue social goals. $28.1 \%$ of third sector organisations succeeded in bidding for contracts from local statutory bodies over the last 5 years.

In terms of financial and human resources, the average income size of third sector organisations in the UK ranges from 17,501 to 20,000 GBP per year. On average, each organisation has two full-time employees and 11-20 volunteers.

In terms of issue areas, the data shows that, the top five issue areas in which third sector organisations work in the UK are education and lifelong learning $(28.8 \%$ of all third sector organisations), leisure including sports and recreation (20.2\%), health and well-being (17.5\%), community development and mutual aid (17.1\%), and religious/faith-based activity $(14.1 \%){ }^{6}$ In terms of geographical regions, $35.1 \%$

\footnotetext{
${ }^{6}$ Similarly, in a recent survey of 1030 social enterprises in nine countries (China, Russia, Germany, Hungary, Portugal, Romania, Spain, Sweden, and the UK), namely "Social Entrepreneurship as a Force for More Inclusive and Innovative Societies" (SEFORÏS), which was conducted between April and December of 2015, "education and research", "employment and training" and "economic, social community development" are the three dominant issue areas where social enterprises are active. The preview of the survey results is provided in the article: "Market-Oriented and Mission-Focused: Social
} 
Table 1 Coding methods and descriptive statistics of all variables

\begin{tabular}{|c|c|c|c|c|c|c|}
\hline Variable & Coding & Obs & Mean & $\begin{array}{l}\text { Std. } \\
\text { Dev. }\end{array}$ & Min & $\operatorname{Max}$ \\
\hline Overall policy influence & \multirow{3}{*}{$\begin{array}{c}1-5(1=\text { very dissatisfied, } \\
5=\text { very satisfied })\end{array}$} & 27,686 & 2.78 & 1.05 & 1 & 5 \\
\hline Policy involvement & & 27,258 & 2.73 & 1.18 & 1 & 5 \\
\hline Policy consulting & & 11,523 & 1.58 & 0.49 & 1 & 2 \\
\hline Social entrepreneurship & \multirow[t]{2}{*}{ Yes $=1$, no $=0$} & 12,206 & 0.45 & 0.50 & 0 & 1 \\
\hline $\begin{array}{l}\text { Achieving government } \\
\text { contracts }\end{array}$ & & 41,781 & 0.28 & 0.45 & 0 & 1 \\
\hline Income size & $1-24$ units, see footnote 5 & 39,026 & 12.14 & 6.70 & 1 & 24 \\
\hline Staff size & \multirow[t]{2}{*}{$1-8$ units } & 41,027 & 2.34 & 1.93 & 1 & 8 \\
\hline Volunteer size & & 41,154 & 3.09 & 1.54 & 1 & 8 \\
\hline $\begin{array}{l}\text { Community development } \\
\text { and mutual aid }\end{array}$ & \multirow[t]{18}{*}{ Yes $=1$, no $=0$} & 40,927 & 0.03 & 0.16 & 0 & 1 \\
\hline Cohesion/civic participation & & 40,927 & 0.01 & 0.09 & 0 & 1 \\
\hline Culture & & 40,927 & 0.04 & 0.20 & 0 & 1 \\
\hline Leisure & & 40,927 & 0.11 & 0.32 & 0 & 1 \\
\hline Economic well-being & & 40,927 & 0.02 & 0.14 & 0 & 1 \\
\hline Accommodation/housing & & 40,927 & 0.04 & 0.19 & 0 & 1 \\
\hline $\begin{array}{l}\text { Education and lifelong } \\
\text { learning }\end{array}$ & & 40,927 & 0.17 & 0.38 & 0 & 1 \\
\hline Training & & 40,927 & 0.06 & 0.24 & 0 & 1 \\
\hline Environment/sustainability & & 40,927 & 0.02 & 0.15 & 0 & 1 \\
\hline Equalities/civil rights & & 40,927 & 0.01 & 0.10 & 0 & 1 \\
\hline Heritage & & 40,927 & 0.04 & 0.20 & 0 & 1 \\
\hline Health and well-being & & 40,927 & 0.15 & 0.35 & 0 & 1 \\
\hline International development & & 40,927 & 0.03 & 0.16 & 0 & 1 \\
\hline $\begin{array}{l}\text { Religious/faith-based } \\
\text { activity }\end{array}$ & & 40,927 & 0.14 & 0.35 & 0 & 1 \\
\hline Criminal justice & & 40,927 & 0.01 & 0.09 & 0 & 1 \\
\hline Animal welfare & & 40,927 & 0.01 & 0.11 & 0 & 1 \\
\hline Capacity building & & 40,927 & 0.06 & 0.23 & 0 & 1 \\
\hline Other field & & 40,927 & 0.05 & 0.22 & 0 & 1 \\
\hline International & \multirow[t]{5}{*}{$\mathrm{Yes}=1, \mathrm{no}=0$} & 43,101 & 0.36 & 0.48 & 0 & 1 \\
\hline National area & & 43,101 & 0.34 & 0.47 & 0 & 1 \\
\hline Regional area & & 43,101 & 0.12 & 0.33 & 0 & 1 \\
\hline Local authority area & & 43,101 & 0.11 & 0.32 & 0 & 1 \\
\hline Neighbourhood area & & 43,101 & 0.07 & 0.25 & 0 & 1 \\
\hline
\end{tabular}

Footnote 6 continued

Enterprises Around the Globe", by Marieke Huysentruyt, Johanna Mair, and Ute Stephan, 19 October 2016. See the link: https://ssir.org/articles/entry/market_oriented_and_mission_focused_social_ enterprises_around_the_globe\#. 
of social sector organisations in the UK are working at the neighbourhood, $32.8 \%$ are at the local authority area, $12.2 \%$ are at the regional level, $11.1 \%$ are at the national level, and $6.5 \%$ are at the international level, and $2.3 \%$ did not answer the question.

To estimate the three dependent variables measuring the policy influence of third sector organisations in the UK, this research uses three ordered logistic regressions in the statistical estimations, as the two dependent variables are ordinal variables. Before the regression analyses, a correlation analysis was conducted to examine the potential correlations among the independent variables. No high correlations were detected. Table 2 presents the results of the regression analyses and reports statistics of the coefficients in the three models.

As reported in Table 2, social entrepreneurship is statistically significant in estimating the satisfaction of third sector organisation on their overall influence on government policies. When a social organisation becomes a social enterprise, its overall satisfaction on its policy influence increased 0.08 unit, when other factors are equal.

Achieving government contrasts for purchasing services is statistically significant in the three models. When a social organisation obtained government contracts, its overall policy influence improved 0.75 unit, its level of involving in policy making increased 0.78 unit, and its likelihoods of being consulting by the government increased 0.80 unit, after controlling for other factors. Therefore, the results verify the Hypothesis 1 that the two indicators of social marketisation are positively related to the policy influence of third sector organisations.

In terms of resources, income size does not significantly affect the level of policy influence of third sector organisations. An organisation with more full-time employees is more likely to involve in policy making, and more likely to be consulted by the government. An organisation with more volunteers is more satisfied with its overall influence on government policies. Therefore, the results partially support Hypothesis 2. Financial resources do not significantly affect the policy influence of third sector organisations, while human resources have a positive effect.

In terms of issue areas and geographical regions, the results show that third sector organisations working in the four issue areas (accommodation/house, heritage, religious/faith-based activities, capacity-building and other support) are more satisfied with their overall capacity to influence government decisions. Third sector organisations working in the four issue areas (cohesion/civic participation, leisure, education and lifelong learning, heritage) are more likely to involve in the process of developing and carrying out policies with the government. Social organisations working in the two fields (cohesion/civic participation and heritage) are more likely to be consulted by the government agencies in the UK. Social organisations active at the international or national level are more likely to involve in government policy making and being consulted by the government, than those organisations operated at the neighbourhood level. Therefore, the results support Hypothesis 3, that issue areas and geographical regions affect the level of influence of third sector organisations on government policies. 
Table 2 Regressions on policy influence of third sector organisations in the UK

\begin{tabular}{|c|c|c|c|}
\hline Variables & $\begin{array}{l}\text { Model } 1 \\
\text { overall policy } \\
\text { influence }\end{array}$ & $\begin{array}{l}\text { Model } 2 \\
\text { policy } \\
\text { involvement }\end{array}$ & $\begin{array}{l}\text { Model } 3 \\
\text { policy } \\
\text { consulting }\end{array}$ \\
\hline Social entrepreneurship & $\begin{array}{l}0.0844 * * \\
(0.0399)\end{array}$ & $\begin{array}{l}0.0137 \\
(0.0397)\end{array}$ & $\begin{array}{l}0.00196 \\
(0.0391)\end{array}$ \\
\hline Achieving govt's contracts & $\begin{array}{l}0.751 * * * \\
(0.0423)\end{array}$ & $\begin{array}{l}0.778 * * * \\
(0.0425)\end{array}$ & $\begin{array}{l}0.799 * * * \\
(0.0417)\end{array}$ \\
\hline Income size & $\begin{array}{l}-0.00517 \\
(0.00460)\end{array}$ & $\begin{array}{l}0.00334 \\
(0.00461)\end{array}$ & $\begin{array}{l}0.00252 \\
(0.00446)\end{array}$ \\
\hline Full-time employee size & $\begin{array}{l}0.0140 \\
(0.0133)\end{array}$ & $\begin{array}{l}0.0527 * * * \\
(0.0133)\end{array}$ & $\begin{array}{l}0.0547 * * * \\
(0.0130)\end{array}$ \\
\hline Volunteer size & $\begin{array}{l}0.0584 * * * \\
(0.0122)\end{array}$ & $\begin{array}{l}0.00782 \\
(0.0121)\end{array}$ & $\begin{array}{l}0.00723 \\
(0.0119)\end{array}$ \\
\hline Issue area-cohesion/civic participation ${ }^{\mathrm{a}}$ & $\begin{array}{l}0.0706 \\
(0.235)\end{array}$ & $\begin{array}{l}0.502 * * \\
(0.241)\end{array}$ & $\begin{array}{l}0.542 * * \\
(0.228)\end{array}$ \\
\hline Issue area-leisure & $\begin{array}{l}0.00417 \\
(0.107)\end{array}$ & $\begin{array}{l}0.181 * \\
(0.107)\end{array}$ & $\begin{array}{l}0.0465 \\
(0.104)\end{array}$ \\
\hline Issue area-accommodation/housing & $\begin{array}{l}0.220 * \\
(0.129)\end{array}$ & $\begin{array}{l}0.119 \\
(0.128)\end{array}$ & $\begin{array}{l}0.0331 \\
(0.126)\end{array}$ \\
\hline Issue area-education and lifelong learning & $\begin{array}{l}0.0153 \\
(0.103)\end{array}$ & $\begin{array}{l}0.229 * * \\
(0.103)\end{array}$ & $\begin{array}{l}0.0882 \\
(0.100)\end{array}$ \\
\hline Issue area-equalities/civil rights & $\begin{array}{l}-0.337 * \\
(0.192)\end{array}$ & $\begin{array}{l}-0.179 \\
(0.187)\end{array}$ & $\begin{array}{l}-0.0969 \\
(0.188)\end{array}$ \\
\hline Issue area-heritage & $\begin{array}{l}0.228^{*} \\
(0.121)\end{array}$ & $\begin{array}{l}0.319 * * * \\
(0.121)\end{array}$ & $\begin{array}{l}0.346 * * * \\
(0.119)\end{array}$ \\
\hline Issue area-religious/faith-based activity & $\begin{array}{l}0.262 * * \\
(0.113)\end{array}$ & $\begin{array}{l}0.152 \\
(0.114)\end{array}$ & $\begin{array}{l}0.0689 \\
(0.111)\end{array}$ \\
\hline Issue area-capacity-building and other support & $\begin{array}{l}0.226^{* *} \\
(0.111)\end{array}$ & $\begin{array}{l}0.128 \\
(0.111)\end{array}$ & $\begin{array}{l}0.110 \\
(0.109)\end{array}$ \\
\hline Geographic area-internationally ${ }^{\mathrm{b}}$ & $\begin{array}{l}0.134 \\
(0.162)\end{array}$ & $\begin{array}{l}0.571 * * * \\
(0.169)\end{array}$ & $\begin{array}{l}0.821 * * * \\
(0.161)\end{array}$ \\
\hline Geographic area-nationally & $\begin{array}{l}0.00198 \\
(0.160)\end{array}$ & $\begin{array}{l}0.488 * * * \\
(0.167)\end{array}$ & $\begin{array}{l}0.757 * * * \\
(0.159)\end{array}$ \\
\hline Geographic area-regionally & $\begin{array}{l}-0.164 \\
(0.163)\end{array}$ & $\begin{array}{l}0.161 \\
(0.170)\end{array}$ & $\begin{array}{l}0.404 * * \\
(0.162)\end{array}$ \\
\hline Geographic area-local authority area & $\begin{array}{l}-0.126 \\
(0.167)\end{array}$ & $\begin{array}{l}-0.00674 \\
(0.175)\end{array}$ & $\begin{array}{l}0.146 \\
(0.166)\end{array}$ \\
\hline $\mathrm{N}$ & 8486 & 8451 & 8745 \\
\hline
\end{tabular}

Standard errors are in parentheses. *** $p<0.01 ; * * p<0.05 ; * p<0.1$

a "Issue area-other" as the reference category. Issue areas that are not statistically significant are omitted

b "Geographic area-neighbourhood" as the reference category 
In sum, the results based on the survey data support the core argument of this research, that is social marketisation is positively related to the policy influence of third sector organisations. When third sector organisations become social enterprises, the level of their perceived policy influence increased. When third sector organisations achieved government contracts for purchasing services, the levels of their overall policy influence, involvement in government policy making, and the chance of being consulted by the government all improved.

\section{Conclusion}

The marketisation of social sector organisations or social marketisation emerged and spread around the world in the past three decades. Social entrepreneurship and achieving government contracts for purchasing services are two salient indicators of the new tendency of social marketisation.

In contrast with existing literature which claims that social marketisation makes social sector organisations reduce their efforts on advocacy and thus harms a strong civil society, this research finds that social marketisation is positively related to the influence of third sector organisations on government policies, and thus it can strengthen the development of civil society, rather than erode it.

Based on the National Survey of Charities and Social Enterprises in the UK, the results of regression analyses show that, when other factors are equal, the two indicators of social marketisation, social entrepreneurship and achieving government contracts for purchasing services, are both statistically significant in estimating the level of policy influence of third sector organisations.

Specifically, when a third sector organisation becomes a social enterprise, its satisfaction on its overall influence on government policies increased 0.08 unit, when other factors are equal. When a social sector organisation achieved government contracts, its overall policy influence improved 0.75 unit, the level of involving in policy making increased 0.78 unit, and the likelihoods of being consulting by the government increased 0.80 unit, when other factors are equal. Therefore, the results support the argument that the two indicators of social marketisation strengthen the policy influence of third sector organisations in the UK.

This research has two main contributions to the literature. Firstly, it finds a positive, rather than a negative, relationship between social marketisation and the perceived policy influence of social sector organisations. In contrast with the research claiming marketisation of the social sector threatens civil society in the USA (Eikenberry 2009; Eikenberry and Kluver 2004; Nickel and Eikenberry 2009), this study suggests that social marketisation in fact can strengthen the development of civil society, by enhancing the policy influence of social sector organisations. Secondly, this research responds to the call to add the diversity to the understanding of policy influence or advocacy in different country contexts, as the majority of the scholarship is based on experiences of social sector organisations in the USA (Almog-Bar and Schmid 2014; Ljubownikow and Crotty 2015).

The limitation of this study is that the policy influence of third sector organisations is measured by self-perceptions and self-reports. The nuanced forms 
and processes of influencing government policies are not considered in this research. Readers may also be curious about what policies are influenced and how they are influenced by social sector organisations. This limitation, however, has been extended by other research that explores how two specific social organisations have successfully promoted the emergence of five new government policies in the Chinese context (Han 2016).

Open Access This article is distributed under the terms of the Creative Commons Attribution 4.0 International License (http://creativecommons.org/licenses/by/4.0/), which permits unrestricted use, distribution, and reproduction in any medium, provided you give appropriate credit to the original author(s) and the source, provide a link to the Creative Commons license, and indicate if changes were made.

\section{References}

Aldrich, H. (1979). Organizations and environments. Englewood Cliffs, NJ: Prentice-Hall.

Aldrich, H. E., \& Pfeffer, J. (1976). Environments of organizations. Annual Review of Sociology, 2(1), 79-105.

Almog-Bar, Michal, \& Schmid, Hillel. (2014). Advocacy activities of nonprofit human service organizations: A critical review. Nonprofit and voluntary sector quarterly, 43(1), 11-35.

Andrews, K. T., \& Edwards, B. (2004). Advocacy organizations in the U.S. Political process. Annual Review of Sociology, 30(1), 479-506.

Bass, G. D., Arons, D. F., Guinane, K., Carter, M. F., \& Rees, S. (2007). Seen but not heard: Strengthening nonprofit advocacy. Washington, DC: The Aspen Institute.

Baumgartner, F. R., \& Leech, B. L. (2001). Interest niches and policy bandwagons: Patterns of interest group involvement in national politics. Journal of Politics, 63(4), 1191-1213.

Child, C. D., \& Grønbjerg, K. A. (2007). Nonprofit advocacy organizations: Their characteristics and activities. Social Science Quarterly, 88(1), 259-281.

Dart, R. (2004). The legitimacy of social enterprise. Nonprofit Management and Leadership, 14(4), 411-424.

Dees, J. G. (1998). "The meaning of social entrepreneurship.” Stanford University: Center for social innovation, graudate school of business. https://entrepreneurship.duke.edu/news-item/the-meaningof-social-entrepreneurship/

DiMaggio, P. J., \& Powell, W. W. (1983). The iron cage revisited: institutional isomorphism and collective rationality in organizational fields. American Sociological Review, 48(2), 147-160.

Donaldson, L. P. (2007). Advocacy by nonprofit human service agencies. Journal of Community Practice, 15(3), 139-158.

Eikenberry, A. M. (2009). Refusing the market: A democratic discourse for voluntary and nonprofit organizations. Nonprofit and Voluntary Sector Quarterly, 38(4), 582-596.

Eikenberry, A. M., \& Kluver, J. D. (2004). The marketization of the nonprofit sector: Civil society at risk? Public Administration Review, 64(2), 132-140.

Hall, K., Alcock, P., \& Millar, R. (2012). Start up and sustainability: marketisation and the social enterprise investment fund in england. Journal of Social Policy, 41(04), 733-749.

Han, J. (2016). The emergence of social corporatism in China: Nonprofit organizations, private foundations and the state. The China Review, 16(2), 27-53.

Han, J. (2013). The state of social enterprises and the criteria of SE certification in the UK (in Chinese). In J. Xu (Ed.), China third sector research (pp. 106-115). Shanghai: Shanghai Jiaotong University Press.

Hsu, J. Y. J., Hsu, C. L., \& Hasmath, R (2016). "NGO strategies in an authoritarian context, and their implications for citizenship: The case of the People's Republic of China." Voluntas: International Journal of Voluntary and Nonprofit Organizations:1-23.

Jenkins, J. Craig. (1983). Resource mobilization theory and the study of social movements. Annual Review of Sociology, 9(1), 527-553. 
Ljubownikow, S., \& Crotty, J. (2015). Nonprofit influence on public policy: exploring nonprofit advocacy in Russia. Nonprofit and Voluntary Sector Quarterly:1-19.

McAdam, D., McCarthy, J. D., \& Zald, M. N. (1988). Social movements. In J. Neil (Ed.), Handbook of sociology. Smelserm. Newbury Park; London: Sage.

McCarthy, J. D., \& Zald, M. N. (1977). Resource mobilization and social movements: A partial theory. American Journal of Sociology, 82(6), 1212-1241.

McKay, S., Moro, D, Teasdale, S, \& Clifford, D (2015). "The marketisation of Charities in England and Wales. Voluntas: International Journal of Voluntary and Nonprofit Organizations 26:336-354.

Meyer, John W., \& Richard Scott, W. (1983). Organizational environments: Ritual and rationality. Beverly Hills; London: Sage Publications.

Meyer, J. W., \& Rowan, B. (1977). Institutionalized organizations: formal structure as myth and ceremony. American Journal of Sociology, 83(2), 340-363.

Mosley, J. E. (2010). Organizational resources and environmental incentives: Understanding the policy advocacy involvement of human service nonprofits. Social Service Review, 84(1), 57-76.

Newman, J. (2007). Rethinking 'the public' in troubled times. Public Policy and Administration, 22(1), 27-47.

Nicholls, A (Ed.). (2006). Social Entrepreneurship: New Models of Sustainable Social Change: Oxford University Press.

Nicholson-Crotty, Jill. (2007). Politics, policy, and the motivations for advocacy in nonprofit reproductive health and family planning providers. Nonprofit and voluntary sector quarterly, 36(1), 5-21.

Nickel, P. M., \& Eikenberry, A. M. (2009). A critique of the discourse of marketized philanthropy. American Behavioral Scientist, 52(7), 974-989.

Pfeffer, J., \& Salanick, G. R. (1978). The external control of organizations: A resource dependence perspective. New York: Harper \& Row.

Powell, W. W., \& DiMaggio, P. J. (Eds.). (1991). The new institutionalism in organizational analysis. Chicago; London: University of Chicago Press.

Salamon, L. M. (1993). The marketization of welfare: Changing nonprofit and for-profit roles in the American welfare state. Social Service Review, 67(1), 16-39.

Schmid, H., Bar, M., \& Nirel, R. (2008). Advocacy activities in nonprofit human service organizations: Implications for policy. Nonprofit and Voluntary Sector Quarterly, 37(4), 581-602.

Schmitter, Philippe C. (1974). Still the century of corporatism? The Review of Politics, 36(1), 85-131.

Scott, W. R. (2004). Reflections on a half-century of organizational sociology. Annual Review of Sociology, 30(1), 1-21.

Scott, W. R. (2001). Institutions and Organizations. Thousand Oaks, Calif.; London: SAGE Publications.

Scott, W. R., \& Christensen, S. (1995). The institutional construction of organizations: International and longitudinal studies. California, London: Thousand Oaks, Sage.

Scott, W. R., \& John W. M. (Eds.). (1994). Institutional environments and organizations: Structural complexity and individualism. Thousand Oaks, Calif; London Sage.

Suárez, D. F., \& Hwang, H. (2008). Civic engagement and nonprofit lobbying in California, 1998-2003. Nonprofit and Voluntary Sector Quarterly, 37(1), 93-112.

Weisbrod, Burton A. (2000). To profit or not to profit: the commercial transformation of the nonprofit sector. Cambridge, UK: Cambridge University Press.

Young, D. R., Salamon, L. M., \& Grinsfelder M. C. (2012). "Commercialization, Social Ventures, and For-Profit Competition." Pp. 521-548 in The State of Nonprofit America, edited by Lester M. Salamon. Washington D.C.: Brookings Institution Press.

Zucker, L. G. (1987). Institutional Theories of Organization. Annual Review of Sociology, 13(1), 443-464. 